\title{
The Effect of Different Dietary Energy and Protein Sources on Blood Profile of Crossbreed Holstein Dairy Cows Raised in Small Stake Holder Farms
}

\author{
Mohammad Firdaus Hudaya, Pradita Iustitia Sitaresmi, and Diah Tri Widayati* \\ Faculty of Animal Science, Universitas Gadjah Mada, Jl. Fauna 3, Bulaksumur, Yogyakarta - 55281, Indonesia \\ *Corresponding author's Email: widayati@ugm.ac.id ; (DORCiD: 0000-0002-6054-4443
}

\begin{abstract}
The study aimed to evaluate the effect of protein and energy supplementation on the biochemical blood parameters in Holstein cows. The effect of energy and protein supplementation used corn and soybean meal was evaluated on biochemical blood profile in three groups of Holstein cows raised in small stakeholder farmers in Yogyakarta from February to May 2020. Thirty multiparous Holstein cows were allocated to three treatment groups, namely $\mathrm{T} 0$ in which the cows fed by the basal diet from the local farmer as well as the $\mathrm{T} 13.5 \%$ energy and protein supplementation) and T2 (5\% energy and protein supplementation), in which the cows were fed by added energy and protein supplementation. The diets designed for the treatment groups were different from the basal diet by adding two additional ingredients which were soybean meal and corn meal in purpose to depress the stress from adaptive feeding. The results showed that the treated cows (T1 and T2) had significantly higher serum concentrations of glucose $(\mathrm{T} 1=2.12 \pm 0.49 \mathrm{mmol} / \mathrm{L}, \mathrm{T} 2=1.86 \pm 0.40 \mathrm{mmol} / \mathrm{L})$ rather than $\mathrm{T} 0(0.98 \pm 0.48$ $\mathrm{mmol} / \mathrm{L}$ ). The total concentration of serum protein and urea in treated cows was significantly lower than those with the basal diet. Total serum protein and urea in T1 were $0.69 \pm 1.37 \mathrm{mmol} / \mathrm{L}$ and $7.21 \pm 1.99 \mathrm{mmol} / \mathrm{L}$, respectively; which they were $0.63 \pm 0.06 \mathrm{mmol} / \mathrm{L}$ and $7.69 \pm 3.07 \mathrm{mmol} / \mathrm{L}$ in $\mathrm{T} 2$, compared to the $\mathrm{T} 0$ which were $0.82 \pm 0.05$ $\mathrm{mmol} / \mathrm{L}$ and $7.69 \pm 3.07 \mathrm{mmol} / \mathrm{L}$, respectively. There was no significant difference in blood cholesterol among all treatment groups. In conclusion, the supplementations that varied in the proportion of energy and protein intake affected some biochemical blood profiles, such as glucose, protein, and blood urea nitrogen.
\end{abstract}

Keywords: Biochemical blood parameters, Crossbreed Holstein cows, Energy supplementation, Protein supplementation, Traditional farmers

\section{INTRODUCTION}

In Indonesia, dairy farms are held mainly by smallholder farmers whose cows are only two to three with low field productivity (Sembada et al., 2016). As most farms have little or no land for foraging, the cows have inadequate nutritional status. This inadequate nutrition is a major constrain that negatively affects animal reproduction (Cordova Izquierdo, 2015). The effect of poor nutrition, which decreases reproductive performance in cows, is causally related to the blood metabolic profile (Ferraretto et al., 2014; Rutherford et al., 2016). The evaluation of blood metabolic profiles is required to monitor the animal's health, reproduction, and physiological conditions (Puppel and Kuczyńska, 2016), which can prevent metabolic and nutritional disorders in cows. Also, the simple method of feed supplementation which is more efficient for those traditional farmers which they could apply easily, when the farmers just put some additional feed ingredients which are available in their location to increase the nutritional values in purpose to increase the animal productivity, rather than changing the whole formulation or adding a significant ingredient which is difficult to find in the area.

Whenever the physiologically and hormonally managed mobilization of energy in cows is not balanced, biological consequences can be observed (Crowe et al., 2018), especially when the mobilization of the body results from Negative Energy Balance (NEB) had a significant effect on the parameter metabolic, milk nutrient values or subsequent health (Sheehy et al., 2016). Protein and energy supplementation are some of the nutritional strategies that have been found to decrease reproductive problems due to the inadequate nutritional status in smallholder farms (Hostens et al., 2011; Cools et al., 2014). Therefore, it is important to determine the most suitable feedstuff to obtain the efficiency of feed formulation. The important key about supplementation is to use it only without changing the whole formulation to enhance the nutritional intake. Protein supplementation, such as soybeans and energy supplementation with corn, could increase the intake and nutritional value of lower-quality feed used by smallholder farmers (Olson, 2015), which are abundant and easy to access, especially in Indonesia or tropical countries.

The present study aimed to evaluate the effects of diets supplemented with soybean meal as a source of protein and corn as a source of energy on the biochemical blood parameters (glucose, protein, cholesterol, and blood urea nitrogen) of Holstein cattle. 


\section{MATERIALS AND METHODS}

\section{Ethical approval}

The procedures applied throughout the current study have been approved by the Animal Care and Use Committee of Faculty of Veterinary Medicine UGM, Yogyakarta Indonesia, No. 002/EC.FKH/Ket/2019

\section{Experimental animals, location, and period of research}

The present study was conducted using 30 Holstein crossbreed cows (with an average age of three years old) raised by smallholder farmers in Yogyakarta, Indonesia with the Body Condition Score (BCS) ranged two to three in two to four periods of lactation. The research was carried out from February to May 2020. The cows were under semi-intensive maintenance, housed in communal pens.

\section{Feeding methods}

The basal diet for the control group (T0, $\mathrm{n}=10$ ) was formulated based on the farmers' daily feed given to the cows with consideration of the BCS (two to three) and milk production ( $8 \mathrm{~kg} /$ days on average of $75 \%$ forages and $25 \%$ commercial concentrate, Table 1). In the treatment groups T1 and T2, the cows were fed with added energy and protein supplementation obtained from soybean and corn meal so the feed formulation was not totally changed (Cools, 2014) which had a purpose to suppress the stress effect from feed factors in animals, so it prevents animal welfare through the study. The treatment diet in $\mathrm{T} 1(\mathrm{n}=10)$ was formulated by replacing $14 \%$ of commercial concentrate in total with an added supplementation of energy and protein which was seven percent of corn meal and seven percent of soybean meal as fed (3.5\% energy and protein supplementation in dry matter $(\mathrm{DM})$. The second treatment $(\mathrm{T} 2 ; \mathrm{n}=10)$ was formulated by replacing $20 \%$ of commercial concentrate in total with an added supplementation of energy and protein by $10 \%$ of corn meal and $10 \%$ of soybean meal as fed (five percent energy and protein supplementation in DM), which all the nutrient intakes and chemical composition of the feeds are shown in Tables 1 and 2 in Dry Matter (DM). The cows were fed individually at 06.00 and 15.00 with ad-libitum water intake.

Table 1. The compositions of ingredient and chemical of the diets

\begin{tabular}{lccc}
\hline Ingredient (\% DM) & T0 & T1 & T2 \\
\hline Pennisetum Purpureum & 73.3 & 69.7 & 69.7 \\
Commercial concentrate & 26.7 & 25.0 & 21.0 \\
Corn & - & 2.65 & 4.65 \\
Soybean meal & - & 2.65 & 4.65 \\
\hline Dry matter (kg) & & & \\
Crude protein (kg) & 7.78 & 8.08 & 8.83 \\
TDN (kg) & 1.36 & 1.56 & 1.71 \\
\hline Rence & 5.20 & 5.48 & 6.06 \\
\hline
\end{tabular}

Reference: Hartadi (1980). T0: Cows were fed by the basal diet from the local farmer, T1: Cows were fed by added energy supplementation, T2: Cows were fed by added protein supplementation.

Table 2. Chemical composition of the forages and concentrates

\begin{tabular}{|c|c|c|c|c|c|c|c|}
\hline \multirow[b]{2}{*}{ Ingredients } & \multicolumn{7}{|c|}{ Proximate analysis (\%) } \\
\hline & $\begin{array}{c}\text { Dry } \\
\text { Matter }\end{array}$ & $\begin{array}{c}\text { Anorganic } \\
\text { Matter (Ash) }\end{array}$ & $\begin{array}{c}\text { Etyl } \\
\text { Ether }\end{array}$ & $\begin{array}{l}\text { Crude } \\
\text { Fibre }\end{array}$ & $\begin{array}{c}\text { Crude } \\
\text { Protein }\end{array}$ & $\begin{array}{c}\text { Nitrogen } \\
\text { Free Extract }\end{array}$ & $\begin{array}{c}\text { Total Digestible } \\
\text { Nutrient }\end{array}$ \\
\hline Pennisetum Purpureum & 21.74 & 13.02 & 8.42 & 29.65 & 13.88 & 13.29 & 86.24 \\
\hline Commercial concentrate & 90.45 & 23.80 & 6.75 & 13.26 & 20.07 & 36.12 & 52.83 \\
\hline Corn & 87.54 & 2.04 & 7.24 & 2.83 & 10.27 & 77.62 & 83.89 \\
\hline Soybean Meal & 87.40 & 7.22 & 4.28 & 5.21 & 56.44 & 26.85 & 80.42 \\
\hline
\end{tabular}

\section{Sampling methods}

The samples of feed and feed residual were collected daily during the data collection period, dried at $55^{\circ} \mathrm{C}$ in the oven for 48 hours, grounded to pass through a $1 \mathrm{~mm}$ screen using a Wiley mill. The feeds and residual feed samples were analyzed for Dry Matter (DM), ash, Crude Protein (CP), Organic Matter (OM), Total Digestible Nutrient (TDN, Nakano et al., 2018).

\section{Blood preparation and blood analysis}

The concentration of biochemical blood profiles, such as glucose, protein, cholesterol, and blood urea nitrogen was determined in the serum samples from 30 cows. The blood samples were collected by tubes via vena jugularis every 
week and centrifuged at $3000 \mathrm{rpm}$ for 15 minutes. Upon complete serum separation, it was transferred to microtubes and stored at $-20^{\circ} \mathrm{C}$ until the analysis. The total amounts of glucose, protein, cholesterol, and urea of the serum were measured using a UV spectrophotometer (Microlab 300, Indonesia; Sitaresmi et al., 2017).

\section{Statistical analysis}

The obtained values expressed as Mean \pm SEM with $95 \%(\mathrm{p}<0.05)$ of the confidence interval for the significant results in each treatment, which were analyzed using univariate linear regression by SPSS, version 26 (IBM, USA).

\section{RESULTS}

As shown in Table 3, cows fed with protein and energy supplementation (T1 and T2) had significantly $(\mathrm{p}<0.05)$ higher serum concentrations of glucose $(\mathrm{T} 1=2.12 \pm 0.49 \mathrm{mmol} / \mathrm{L}, \mathrm{T} 2=1.86 \pm 0.40 \mathrm{mmol} / \mathrm{L})$ than cows who consumed only the basal diet provided by the smallholder farmers $(\mathrm{T} 0=0.98 \pm 0.48 \mathrm{mmol} / \mathrm{L})$. However, there was no significant difference in blood glucose levels in the serum between the T1 and T2 treatment groups $(\mathrm{p}>0.05)$. The treated cows (T1 and T2) had significantly $(\mathrm{p}<0.05)$ lower concentrations in serum protein and urea rather than the cows fed by the basal diet (T0). The protein concentration in T0, T1 and T2 were $0.82 \pm 0.05,0.69 \pm 0.1 .37$, and $0.63 \pm 0.06 \mathrm{mmol} / \mathrm{L}$, respectively. The urea concentrations in T0, T1, and T2 were $12.23 \pm 2.22,7.21 \pm 1.99$, and $7.69 \pm 3.07 \mathrm{mmol} / \mathrm{L}$, respectively (Table 3). However, there was no significant difference ( $p>0.05)$ in blood protein and urea serum levels between T1 and T2. There was no significant difference $(\mathrm{p}>0.05)$ in blood cholesterol among all the treatment groups.

Table 3. Biochemical blood concentrations of the cows fed with diets containing different amounts of energy and protein

\begin{tabular}{lccc}
\hline Parameter & T0 & T1 & T2 \\
\hline Glucose (mmol/L) & $0.98 \pm 0.48^{\mathrm{c}}$ & $2.12 \pm 0.49^{\mathrm{ab}}$ & $1.86 \pm 0.40^{\mathrm{ab}}$ \\
Cholesterol (mmol/L) & $4.84 \pm 0.94$ & $4.69 \pm 1.59$ & $5.49 \pm 0.62$ \\
Protein (g/L) & $0.82 \pm 0.05^{\mathrm{a}}$ & $0.69 \pm 1.37^{\mathrm{bc}}$ & $0.63 \pm 0.06^{\mathrm{bc}}$ \\
Urea (mmol/L) & $12.23 \pm 2.22^{\mathrm{a}}$ & $7.21 \pm 1.99^{\mathrm{bc}}$ & $7.69 \pm 3.07^{\mathrm{bc}}$ \\
\hline
\end{tabular}

$\mathrm{a}, \mathrm{b}, \mathrm{c}$ Total means with different superscripts within a row differ significantly ( $\mathrm{p}<0.05)$. T0: cows were fed with the basal diet from the local farmer, T1: cows were fed with added energy supplementation, T2: cows were fed with added protein supplementation.

\section{DISCUSSION}

The result showed that the energy and protein supplementation affected some of the blood profiles of cows. These findings were similar to those reported in previous studies (Ferraretto et al., 2014). Supplementation in lactating cows can enhance physiological and reproduction parameters (McLean et al., 2018). The supplementation used in the present study has affected the levels of insulin and IGF-1 which can lead to differences in the blood profile glucose, which is an indication of supplementation efficiency (Lents et al., 2005). An increased concentration of serum glucose with protein and energy supplementation increased nutrient availability. The data about glucose were similar to the current results (Table 3), the addition of feed supplementation increased serum glucose due to the increased gluconeogenesis in the tissue owing to raise insulin levels. In cows, blood glucose is mainly produced via hepatic gluconeogenesis in the liver (Goselink et al., 2013), so the supplementation of feed protein and energy could increase the gluconeogenesis in cells using the excess of energy and protein feed. It has been previously reported that protein and energy supplementation decreased liver triglyceride deposition (Elek et al., 2013), serum $\beta$-hydroxybutyrate (BHBA), Non-Esterified Fatty Acids (NEFA) concentration, and increased liver health in cows; however, supplementation did not significantly $(\mathrm{p}>0.05)$ increase the energy and protein levels in T1 and T2 groups (Sun et al., 2016). The nutrient content notably the protein and energy from the basal diet by the farmers (T0) was inadequate which were $1.36 \mathrm{~kg}$ for protein and $5.20 \mathrm{~kg}$ for total digestible nutrient (TDN) meanwhile the minimum requirement for those nutrients were $1.38 \mathrm{~kg}$ for protein and $5.6 \mathrm{~kg}$ for TDN (NRC, 2005). In this condition can be concluded that those cows were in deficiency status or the negative energy balance (NEB). This negative status was indicated by the low glucose levels recorded in serum, and the creation of ketone bodies in blood from the lipid metabolic cycle. These findings were similar to those of other studies ( Wu et al., 2013; Sun et al., 2016). Higher glucose levels in the blood serum, within the normal range, could be a noble indicator of energy. In addition, glucose is a key nutrient that affects ovarian activity in ruminants, which influences the rates of steroidogenesis and gonadotropin synthesis as well as their secretion (Sitaresmi et al., 2017). Therefore, protein and energy supplementation could increase the reproduction in cows. Protein and energy supplementation could increase the breakdown of protein synthesis via methionine and choline mechanisms to increase milk production (Ardalan et al., 2011), which likely influenced the tendency observed in the current study toward a lower protein serum level in the 
treatment diets than that of the basal diet. The lower results of protein serum in treatment cows (T1 and T2), compared to the control group, were due to the supplemented protein. In other words, soybean meal was given freshly without any protein protection treatments or agents, such as aldehydes or tannins, which could lead to high bypass potetionals through direct absorption by the small intestine as amino acids. However, those proteins were easily breakdown by rumen microbes to volatile fatty acids (VFAs) as the main ingredients for gluconeogenesis later and produced glucose as the main energy which was proven significantly by increased glucose serum in treatment cows as the main products of gluconeogenesis (Widyobroto et al., 2008). The supplementation of energy and protein feed could diminish serum ketones or blood urea (BUN) concentrations by varying NEFA and BHBA serum concentrations (Ardalan et al., 2011). Present results indicated that supplementation of protein and energy in feed significantly reduced the BUN levels in cows (Table 3). The basal diet, which did not meet the energy requirements, tended to have a nutritional imbalance of urea at levels higher than $12.5 \mathrm{mmol} / \mathrm{L}$ and the BUN limit was below $7.14 \mathrm{mmol} / \mathrm{L}$ for normal reproduction. If the cows possess a higher level of BUN, these conditions could lead to reproductive impairment, such as repeat breeding, caused by the obstruction of gonadotropins hormones or other factors due to high BUN levels (Widayati et al., 2019). This condition was not caused by a high protein intake from the feed, but rather by an imbalance or deficiency in nutrients. Such imbalance leads to increased levels of triglycerols being mobilized from adipose tissue to generate the necessary energy and the production of urea as a side metabolite (Humer et al., 2016). The obtained results of the present study showed that the supplementation of energy and protein in feed tended to be in the normal reported range of $12.5-18 \mathrm{mmol} / \mathrm{L}$ (Umar et al., 2015). The data from the current study indicated that the addition of protein and energy as supplements could increase the ability of cows to utilize nutrients effectively and efficiently.

Cholesterol is a source of energy and a precursor of steroid reproductive hormones, which are also required for cell function. Similar to this study, supplementation protein and energy has been found to decrease the serum lipid and cholesterol content in the blood (Goselink et al., 2013; Sun et al., 2016, Table 3). The reason is that the protein could enhance complete hepatic oxidation of serum NEFA and acetyl-CoA from mitochondria $\beta$-oxidation of $\mathrm{CO}_{2}$ and $\mathrm{H}_{2} \mathrm{O}$. Protein and energy supplementation increased lipid transfer from the blood to the liver, and stimulated further activation of gluconeogenesis (Tharwat et al., 2012; Goselink et al., 2013; Sun et al., 2016). The decrease in cholesterol concentration in blood serum during feed supplementation, although not significant, was a good indicator of reproductive potential (Sitaresmi et al., 2017). As reported in a previous study, cholesterol serum was positively correlated with ovarian disorders, which could cause impairment of reproductive status in ruminants (Samarutel et al., 2008).

\section{CONCLUSION}

The basal diet provided by the smallholder farmers resulted in a negative energy balance in cows, which was shown by the lower glucose levels and higher blood urea concentrations in the biochemical blood profile of Holstein crossbred cows. Feed supplementations that varied in the proportion of energy and protein intake affected some biochemical blood profile markers such as glucose, proteins, and urea. The protein and energy supplementation were increased blood glucose, and decreased protein and urea of the blood serum, therefore the cholesterol level was not different in all treatments.

\section{DECLARATION}

\section{Acknowledgments}

The author would thank the Ngupoyo Makmur Dairy Farm, for providing facilities to conduct current research and Universitas Gadjah Mada for partially sponsoring the research through the Rekognisi Tugas Akhir Grant (2488/UN1.P.III/DIT-LIT/PT/2020) and also for English proofreading of the article.

\section{Authors' contribution}

Hudaya and Widayati conceived, conducted the fieldwork, administrated, drafted the manuscript and performed the statistical analysis, and reviewed the manuscript. Sitaresmi conducted a literature search. Widayati designed and supervised the study. All authors conducted data interpretation, edited the manuscript, read and approved the final manuscript.

\section{Competing interests}

The authors of the present study declared that there is no financial conflict related to this work, which can negatively impact its publication.

\section{Ethical considerations}

Ethical issues (including plagiarism, consent to publish, misconduct, data fabrication and/or falsification, double publication and/or submission, and redundancy) have been checked by the authors. 
Ardalan M, Dehghan-Banadaky M, Rezayazdi K, and Ghavi Hossein-Zadeh N (2011). The effect of rumen-protected methionine and choline on plasma metabolites of Holstein dairy cows. The Journal of Agricultural Science 149: 639-646. DOI: https://www.doi.org/10.1017/S0021859610001292

Cools S, Van den Broeck W, Vanhaecke L, Heyerick A, Bossaert P, Hostens M, and Opsomer G (2014). Feeding soybean meal increases the blood level of isoflavones and reduces the steroidogenic capacity in bovine corpora lutea, without affecting peripheral progesterone concentrations. Animal Production Science 144: 79-89. DOI: https://www.doi.org/10.1016/j.anireprosci.2013.12.008

Cordova Izquierdo A (2015). Best Practices in animal reproduction: impact of nutrition on reproductive performance livestock. Advances in Dairy Research, 4: 2-5. DOI: https://www.doi.org/10.4172/2329-888x.1000152

Crowe MA, Hostens M, and Opsomer G (2018). Reproductive management in dairy cows - The future. Irish Veterinary Journal, 71: 1-13. DOI: https://www.doi.org/10.1186/s13620-017-0112-y

Elek P, Gaál T, and Husvéth F (2013). Influence of rumen-protected choline on liver composition and blood variables indicating energy balance in periparturient dairy cows. Acta Veterinaria Hungarica, 61: 59-70. DOI: https://www.doi.org/10.1556/AVet.2012.053

Ferraretto LF, Gencoglu H, Hackbart KS, Nascimento AB, Dalla Costa F, Bender RW, Guenther JN, Shaver RD, and Wiltbank MC (2014). Effect of feed restriction on reproductive and metabolic hormones in dairy cows. Journal of Dairy Science, 97: 754-763. DOI: https://www.doi.org/10.3168/jds.2013-6925

Goselink RMA, van Baal J, Widjaja HCA, Dekker RA, Zom RLG, de Veth MJ, and van Vuuren AM (2013). Effect of rumen-protected choline supplementation on liver and adipose gene expression during the transition period in dairy cattle. Journal of Dairy Science, 96: 1102-1116. DOI: https://www.doi.org/10.3168/jds.2012-5396

Hartadi, H (1980). Tables of feed composition for Indonesia. International Feedstuffs Institute. Utah Agriculture Experiment Station. Utah University. Logan. Utah.

Hostens M, Fievez V, Vlaeminck B, Buyse J, Leroy J, Piepers S, De Vliegher S, and Opsomer G (2011). The effect of marine algae in the ration of high-yielding dairy cows during transition on metabolic parameters in serum and follicular fluid around parturition. Journal of Dairy Science, 94: 4603-4615. DOI: https://www.doi.org/10.3168/jds.2010-3899

Humer E, Khol-Parisini A, Metzler-Zebeli BU, Gruber L, and Zebeli Q (2016). Alterations of the lipid metabolome in dairy cows experiencing excessive lipolysis early postpartum. PLoS One, 11: 1-18. DOI: https://www.doi.org/10.1371/journal.pone.0158633

Lents CA, Wettemann RP, White FJ, Rubio I, Ciccioli NH, Spicer LJ, Keisler DH, and Payton ME (2005). Influence of nutrient intake and body fat on concentrations of insulin-like growth factor-I, insulin, thyroxine, and leptin in plasma of gestating beef cows. Journal of Animal Science, 83: 586-596. DOI: https://www.doi.org/10.2527/2005.833586x

McLean KJ, Boehmer BH, Spicer LJ, and Wettemann RP (2018). The effects of protein supplementation of fall calving beef cows on pre-and postpartum plasma insulin, glucose and IGF-I, and postnatal growth and plasma insulin and IGF-I of calves. Journal of Animal Science, 96: 2629-2639. DOI: https://www.doi.org/10.1093/jas/sky173

Nakano M, Matoba K, and Togamura Y (2018). An estimation for total digestible nutrients in fresh herbage from a perennial ryegrass - White clover mixed pasture. Japan Agricultural Research Quarterly, 52: 155-161. DOI: https://www.doi.org/10.6090/jarq.52.155

NRC (2005). National Science Education Standards. Washington DC. National Academy Press.

Olson KC (2015). Cow Supplementation: Getting the Best Bang for Your Buck. Proceedings, Range Beef Cow Symposium,

24: $\quad 163-175$.

Available

at

https://digitalcommons.unl.edu/cgi/viewcontent.cgi?article=1352\&context=rangebeefcowsymp

Puppel K, and Kuczyńska B (2016). Metabolic profiles of cow's blood; a review. Journal of the Science of Food and Agriculture, 96: 4321-4328. DOI: https://www.doi.org/10.1002/jsfa.7779

Rutherford AJ, Oikonomou G, and Smith RF (2016). The effect of subclinical ketosis on activity at estrus and reproductive performance in dairy cattle. Journal of Dairy Science, 99: 4808-4815. DOI: https://www.doi.org/10.3168/jds.2015-10154

Samarutel J, Ling K, Waldmann A, Jaakson H, Kaart T, Leesma A, and Samaru J (2008). Field trial on progesterone cycles, metabolic profiles, body condition score and their relation to fertility in estonian holstein dairy cows. Reproduction in Domestic Animals, 43: 457-463. DOI: https://www.doi.org/10.1111/j.1439-0531.2007.00935.x

Sheehy MR, Fahey A, Aungier SPM, Carter F, Crowe MA, Mulligan FJ (2016). A comparison of serum metabolic and production profiles of dairy cows that maintained or lost body condition 15 days before calving. Journal of Dairy Science, 100: 1-12. DOI: https://www.doi.org/10.3168/jds.2016-11206

Sembada P, Duteurtre G, Purwanto BP, and Suryahadi (2016). Improved milk production performance of smallholder 
farms in West Java (Indonesia). Tropical Animal Health and Production, 48: 793-799. DOI: https://www.doi.org/10.1007/s11250-016-1029-2

Sitaresmi PI, Widyobroto BP, Bintara S, and Widayati DT (2017). Progesterone and biochemical profile of ettawasaanen crossbreed goats in Turi Area, Yogyakarta-Indonesia. International Journal of Dairy Science, 12: $289-294$. DOI: https://www.doi.org/10.3923/ijds.2017.289.294

Sun F, Cao Y, Cai C, Li S, Yu C, and Yao J (2016). Regulation of nutritional metabolism in transition dairy cows: Energy homeostasis and health in response to post-ruminal choline and methionine. PLoS One, 11: 1-27. DOI: https://www.doi.org/10.1371/journal.pone.0160659

Tharwat M, Endoh D, and Oikawa S (2012). Hepatocyte apoptosis in dairy cows with fatty infiltration of the liver. Research in Veterinary Science 93: 1281-1286. DOI: https://www.doi.org/10.1016/j.rvsc.2012.03.011

Umar M, Kurnadi B, Rianto E, Pangestu E, and Purnomoadi A (2015). The effect of energy level of feeding on daily gain, blood glucose and urea on Madura cattle. Journal of the Indonesian Tropical Animal Agriculture 40: 159166. DOI: https://www.doi.org/10.14710/jitaa.40.3.159-166

Widayati DT, Adiarto, Widyobroto BP, and Suranindyah YY (2019). Cortisol and blood urea nitrogen profiles in fertile and repeat-breeder Holstein-Friesian crossbred cows. Pakistan Journal of Biological Sciences 22: 356-360. DOI: https://www.doi.org/10.3923/pjbs.2019.356.360

Widyobroto BP, Priyono S, and Agus A (2008). Effect of Underaded Protein and Energy Level on Intake and Digestibility of Nutrient and Blood Metabolite in Dairy Cows. Animal Production, 5(10): 96-101. https://media.neliti.com/media/publications/64743-ID-none.pdf

Wu F, Jin Z, and Jin J (2013). Hypoglycemic effects of glabridin, a polyphenolic flavonoid from licorice, in an animal model of diabetes mellitus. Molecular Medicine Reports, 7: 1278-1282. DOI: https://www.doi.org/10.3892/mmr.2013.1330 